\title{
圧力振動場における高粘性流体中の微小気泡列の近傍流れに関する実験的考察
}

\section{Experimental consideration about the flow around small bubbles in the high viscous fluid under pressure oscillating field}

\author{
○ 野口 真宜 （名エ大） 村上 佳祐（名エ大） \\ 正岩田 修一（名エ大）森 秀樹 (名エ大)
}

Shingi NOGUCHI, Nagoya Institute of Technology, Gokiso-cho, Nagoya, Aichi, 466-8555

Keisuke MURAKAMI, Nagoya Institute of Technology, Gokiso-cho, Nagoya, Aichi, 466-8555

Shuichi IWATA, Nagoya Institute of Technology, Gokiso-cho, Nagoya, Aichi, 466-8555

Hideki MORI, Nagoya Institute of Technology, Gokiso-cho, Nagoya, Aichi, 466-8555

\begin{abstract}
We have developed the Pressure-Oscillating Defoaming for removing air bubbles from shear-thinning fluids. When there are two air bubbles, the under-bubble rises earlier than the upper air bubble. In the fluid between air bubbles, hydrodynamic interaction occurs and there is a complicated flow. We installed air bubbles in the ink sheet, traced the motion of the ink, and analyzed the flow. The flow between 2 air bubbles was analyzed using the inked racer method. It turns out that the tracer particle with bottom air bubbles is moving from the tracer particle of upper air bubbles, and the complicated flow has occured near the bottom air bubbles
\end{abstract}

Key Words: Viscoelastic, defoaming, visualization

\section{1. 緒 言}

高粘性の流体に対する気泡除去のニーズは多い. 多くの流 体がShear-thinning性を示すことに注目し, 筆者らは, 気泡近 傍の流体特性を意図的に変化させる方法を検討している. そ れは，気泡に圧力振動場を与える方法である。Fig.1に示すよ うに，セル下部より圧力振動を与えることにより，Fig.2の如 く、気泡上昇速度が向上する効果が得られた ${ }^{(1)}$. 同様の方法 で， 2 気泡を上下に設置した場合, 気泡上昇速度は, 上側の 気泡の上昇速度よりも下側に位置する気泡上昇速度が増加 した ${ }^{(2)}$. 圧力振動の印加により, 気泡は膨張と収縮を振動印 加周波数に応じて繰り返すが, 高々直径 $1 \mathrm{~mm}$ 程度の気泡近傍 での减少であり，上側気泡の近傍流れと，下側近傍流れがど のように異なるかが明瞭ではない. そこで, 今回, 微細なイ ンクトレーサー膜を用いる方法を開発し,

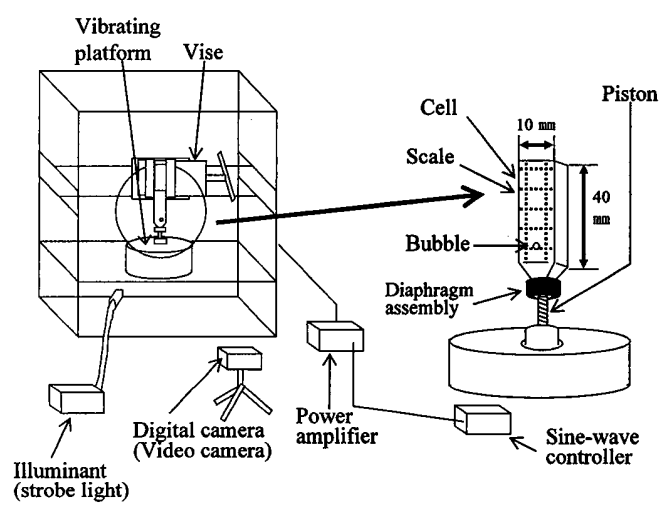

Fig.1 Experimental apparatus

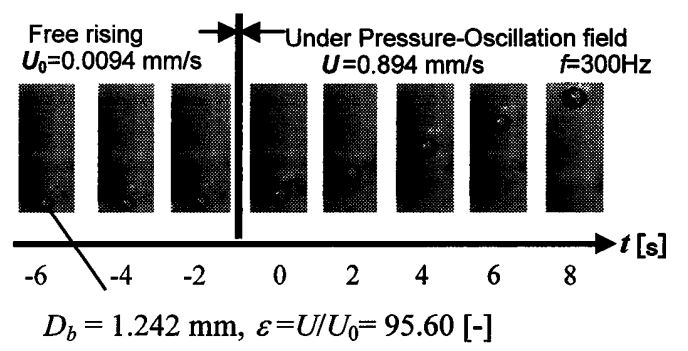

Fig.2 Effect of pressure-oscillation on the $1 \mu \mathrm{L}$-bubble rising velocity.
セル内の気泡近傍流れの可視化を試みた.

\section{2. 実験方法}

試料溶液は $0.8 \mathrm{wt} \%$ ポリアクリル酸ナトリウム水溶液 (SPA) である. 可視化には，ポリスチレン粒子を用いることも考え られる。固体粒子には剪断場における粒子同士の接近現象が 知られている。また, コロイドを形成することも知られてい ることから，取り扱いには注意が必要である，そのため，さ らに微細な粒子群がほぼ同じ密度の溶媒に分散した顔料系イ ンクを用いた. 顔料系インクは, 圧力振動で形成される流動 場に応じて変形できるため, 剪断場における固体粒子同士の 接近現象は軽減される。

密閉可能なガラスセル中に溶液を満たした後, トレーサー として顔料系赤インクの微小液滴を, Fig.3に示すように薄膜 状に設置する.トレーサー面を横切る様に気泡を 2 個設置し, 振動周波数とわずかに異なる周波数にてストロボライトで照 射する. その様子は, 高解像度デジタルビデオカメラ (Sony HDR-HC1)により, 薄膜に対し鉛直方向より撮影する. 動画ファ イルを画像データとして加工後, 気泡ならびにトレーサーの 位置を参照スケールにより求めた. 並行して, 気泡膨張時と 収縮時の画像データを 5 周期分測定し, 気泡形状とトレー サーの移動方向を求めた.

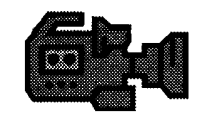

Hi-Density camera

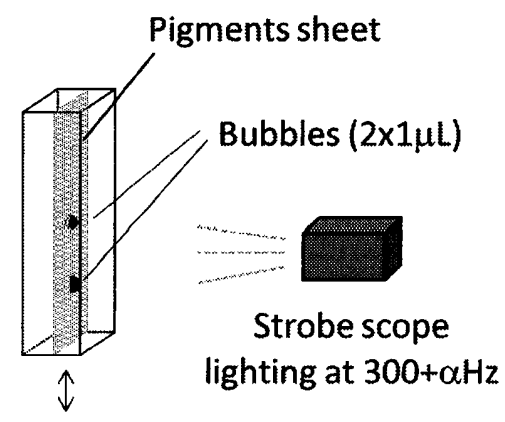

Pressure-oscillating at $300 \mathrm{~Hz}$

Fig.3 Visualization of flow around bubbles by sheet of pigments. 


\section{3. 結果と考察}

Fig.4 はトレース解析のために 動画から抽出した図の 1 つであ る.上下に気泡が設置されており， その周りに微小のトレーサーが 分布する様子がわかる. 図中の○ 印の中に解析に用いたトレー サーがある.上側気泡と下側気泡 の左側に位置するトレーサーに 注目し, 気泡表面近傍, 気泡から 気泡直径程度に離れた点, それら 2 点の中間に近いトレーサーの 3 点ずつ選択する. 気泡上側の 3 点には, 気泡表面に近い液滴から 順に $1,2,3$ と番号をつけた。 下側

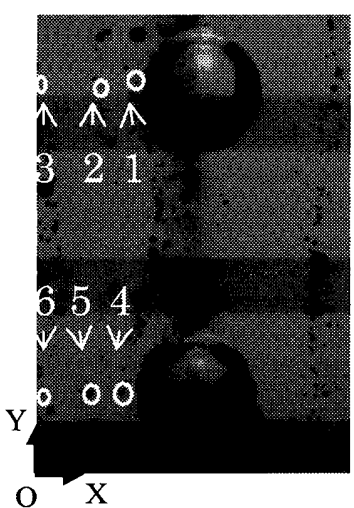

Fig.4 The experiment picture in two air bubbles

気泡には，同様に 4,5,6を与えた. 原 点は, 画像左下に あり，X軸， Y 軸 を図のように設 定した.

Fig.5 は，上側 気泡と下側気泡 の中心座標を，5 周期分について ビデオで録画さ れた時間を用い て示したもので ある. 3 秒間に 5 周期あることか ら，ストロボ発信 周 波 数は， $300.6 \mathrm{~Hz}$ であるこ とがわかる。上側 気泡は, 図中上側 (a)に示されてお り, 中心座標は, 気泡の膨張収縮 に伴ってわずか に変動しながら 上昇することが わかる。これは, 圧力振動が下側 から印加された ため, 中心座標は 収縮時にわずか に上昇すること による、一方，下 側気泡(b)に注目 すると, 気泡中心 位置の上下変動 幅が上側より大 きいことがわか る. 下側気泡の上 下変動幅は, 上側 気泡のほぼ 2 倍 であった。これは， 物質収支の観点
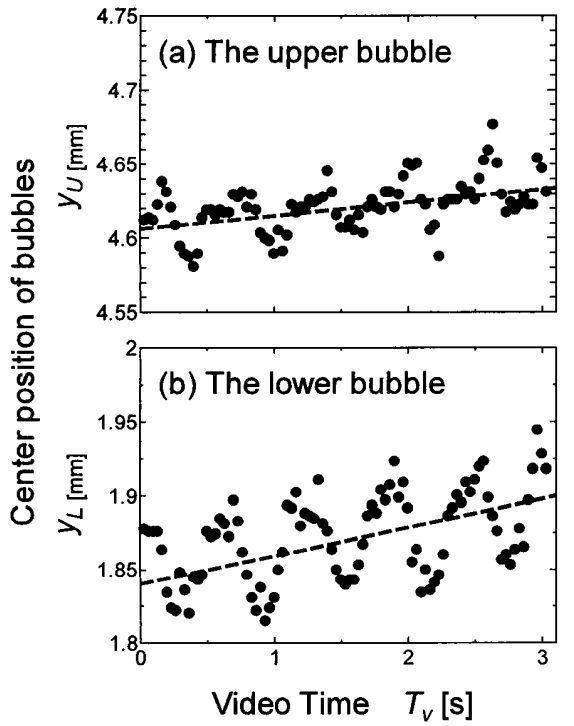

Fig.5 Center position of two bubbles. (a): the upper bubble, (b): the lower bubble
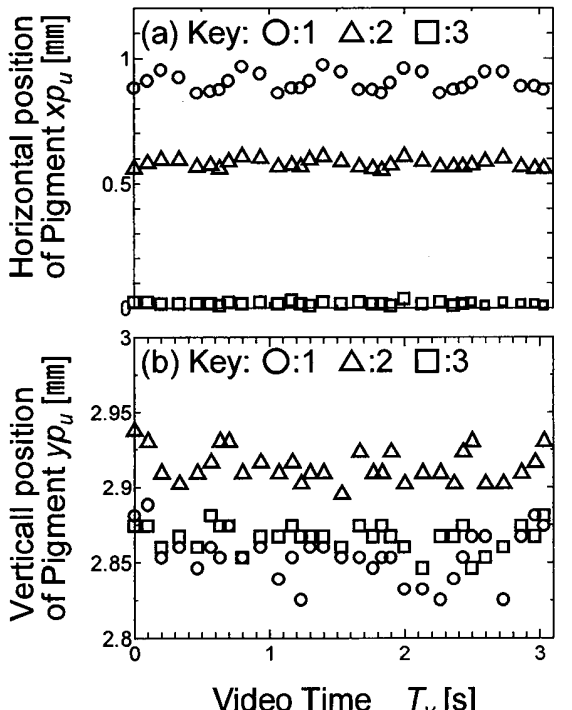

Fig.6 Horizontal and vertical movement of pigments around the upper bubble under pressure-oscillating field.
から考えると，ほぼ妥当な結果と考えられる. 紙面の都合上, 気泡径の変位の時間変化を示していないが, 気泡径の変化, すなわち, 最大気泡径と最小気泡径の差は $0.25 \mathrm{~mm}$ 程度で
あった. 今回示した 上下気泡の中心座 標の変化量と気泡 径の変化量はその 值よりも小さいこ とから, 気泡の収縮 時を比較すると, 気 泡表面間の距離が 拡大することを示 している.

次に, 図中に示し た破線は，それぞれ の平均的な気泡中 心位置を示したも のである.この傾き から気泡上昇速度 を計算できる.下側 気泡の気泡上昇速 度は, 上側気泡上昇 速度の 2.1 倍である ことがわかる。
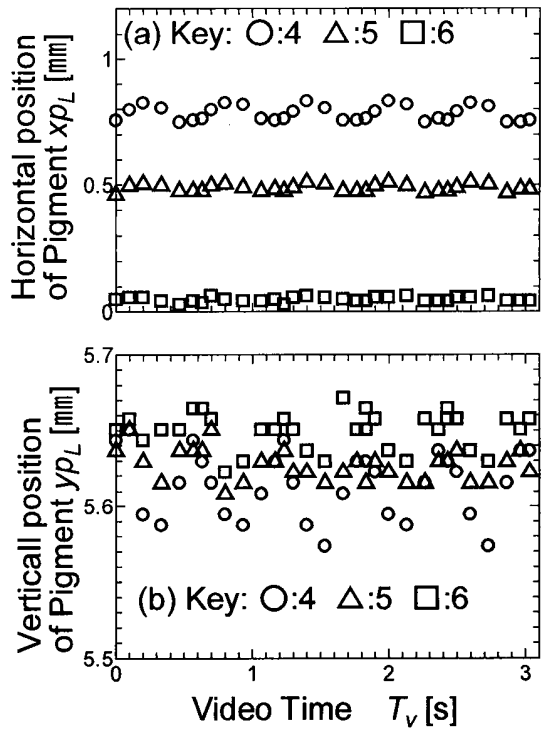

Fig.7 Horizontal and vertical movement of pigments around the lower bubble under pressure-oscillating field.

Fig.6 は, 上側気 泡近傍のトレー サーの動きを示したものである.横軸はビデオカメラで撮影 した時間であり，Fig.5 と同じスケールである. 図中，(a)は $\mathrm{X}$ 軸方向の座標のプロットである、気泡近傍の○印では，気 泡の膨張収縮に伴うサイン波状の変位を示すが，その変位は， 気泡近傍から離れるにつれて減衰する。，一方，Y 軸方向の変 位を表す(b)に注目すると, 気泡近傍の変位は, 若干大きいも のの, 気泡表面から離れるにつれて, 変動量は減衰した。こ のことから，上側気泡では，主に放射状の流れが存在してい ることを表す。

Fig.7 は，下側気泡近傍のトレーサーの動きを示したもの である. 図中上側の気泡近傍の X 軸方向の変位は, 上側気泡 と同様に気泡表面から離れるにつれて, 変動量が減衰した. しかし，Y 軸方向の変動量に注目すると, 気泡表面から最も

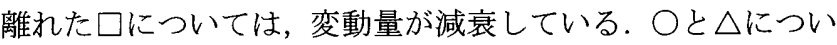
て注目すると，2つの膨張・収縮の位相が，少しずれている ことに気づく.たとえば, 最も気泡表面に近い○では, $T_{v}=0.9 \mathrm{~s}$ にて極小值を示寸が，少し離れた $\triangle$ では， $T_{\nu}=0.8 \mathrm{~s}$ にて極小 值を示した。これは，上側気泡では見られなかった現象であ り，下側気泡でより複雑な流動を呈していることを示唆して いる。しかしながら，下側気泡近傍で生じた複雑な流動の全 体像を把握するには，さらなるデータの蓄積が必要であり， さらに2 次元的な解析からその構造の解明を進める予定であ る.

\section{4. 結 言}

高粘性の粘弾性流体中に薄膜シート状に設置された微小 液滴群によるインクトレーサー法により, 圧力振動場におい て, 上下に設置された 2 気泡の気泡近傍流体の流れの解析を 行った。 上側気泡の近傍では，放射状の流れが主であるが， 下側気泡の近傍では, より複雑な流動が存在することが認め られた。

引用文献

(1) 山田ら, 日本機械学会流体工学部門講演会,612 講演 (2007)

(2) 岩田ら,日本機械学会年次大会,S0501-3-4 講演(2009) 